\title{
Possible ways of IP Commercialisation in the European Higher Education Ecosystem
}

\author{
Z. PEREDY ${ }^{1}$, B. LAKI ${ }^{1}$ \\ 1Edutus University, Engineering Institute H-2800 Tatabánya, Stúdium tér 1. \\ peredy.zoltan@edutus.hu; laki.balazs@edutus.hu
}

\begin{abstract}
Strong links between universities, and companies can play crucial role in promoting taking into practice of ideas that drive the knowledge society, and in raising competitiveness and living standards. In academic terms of IP management, all activities aimed at sharing knowledge generated in research institutions as a knowledge transfer including scientific publishing, conference presentations, collaborative research with external partners, and contractbased clustering activities, such as licensing and spin-offs. In a narrower sense, the IP management means technology transfer is aimed at placing a given technology on the market, and includes any process by which the recovery partner becomes able to produce new products or services. IP with traditional university mission, values, and activities primarily focusing an active university role in entrepreneurship and contracts with private sector for IP commercialization. This paper gives a comprehensive overview about IP management in universities of the European Higher Education System including the following aspects: partnerships (licensing, industry collaborators); IP invention (disclosures, patenting); proof of concept research bridging the gap between lab discoveries and market application (highly innovative $R \& D$ to solve practical problems and commercialization research aiming patented technologies towards business exploitations) and commercialization (start-up incubators and strengthening the entrepreneurial attitudes and competencies). The methodology based on secondary research analysing EU, OECD, online literature sources and relevant, up-to date statistical data as well. The conclusions and recommendations based on this „desk research" work reflects the authors.
\end{abstract}

Keywords: IP management, commercialization, knowledge transfer, contracts, university entrepreneurship role

\section{Introduction}

Currently, the European Higher Education System is facing unprecedented challenges due to economic and social/demographic trends of globalisation. These emerging trends have crucial influence on the traditional higher education system's original mission, reshaping its "service portfolio" and organizational structure. Largely due to these transformation processes, the "third-generation (entrepreneur) universities" gained increasingly importance, where besides the traditional educational and R\&D activities they make efforts to take into practice the market-oriented knowledge-exploitation (commercialization) projects predominantly business purposes.

Based on the international experiences, due to digitization, Industry 4.0, artificial intelligence and the digital transformation of eco-systems, intellectual property (IP) can be one of the central elements related to the knowledge-based economy, which is the main pillar of the sustainable economic growth 
and competitiveness. The digitalisation era in information and communication technologies (ICT) has dramatically cut the costs and the life cycle of the different innovation processes inside the whole European Union, including creating, processing and transmitting knowledge as well. On the other hand, the emerging needs for closer links to business sphere and contributing to solve real social and economic problems generates new challenges for IP regimes, especially managing and protecting properly IP rights and at the same time, accelerating the commercialization process providing institutional conditions and initiatives make more efficient and effective the IP system besides the legal framework.

This paper providing comprehensive overview related to IP management - this complex process of inputs, outcomes, and impact - in universities of the European Higher Education System, including the following aspects: partnerships (licensing, industry collaborators); IP invention (disclosures, patenting); proof of concept research bridging the gap between lab discoveries and market application (highly innovative R\&D to solve practical problems and commercialization research aiming patented technologies towards business exploitations) and commercialization (start-up incubators and strengthening the entrepreneurial attitudes, competencies). In addition, several international best practices in this field will be thoroughly analysed and finally making recommendations for the decision makers and every involved stakeholder in the field of university IP commercialization.

\section{Methodology}

The international review is based on secondary or 'desk research' research methods (review of existing relevant EU, OECD, WIPO documents, publications, selected case studies, on-line web pages and then systematization, selection and analysis of data collected in this way). The main conclusions and lessons drawn from the analysis of the concrete example based on international experience reflect the author's own professional opinion.

\section{The types and the importance of the intellectual assets at universities. The reasons for commercialization [1]; [2]; [3]; [4]; [5]}

IP in broad context strongly related to all types of activity of universities. Codified knowledge, R\&D outcomes, tacit knowledge, know-how, technology ideas, publications and a huge range of copyright material and the human connections that empowering the different scientific fields to exploiting and multiplying the hidden synergies between them - all these things feed through and emerge from R\&D and innovations, teaching, consultancy, and the many other things, that belong to the universities mission.

In academic terms of IP management, all activities aimed at sharing knowledge generated in research institutions as a knowledge transfer. Typically, this includes scientific publishing, conference presentations, collaborative research with external partners, and contract-based clustering activities, such as licensing and spin-offs. In a narrower sense, the IP management means technology transfer is aimed at placing a given technology on the market, and includes any process by which the recovery partner becomes able to produce new products or services. In this context, it is important to realize such kind of IP Policy that integrates IP with traditional university mission, values, and activities primarily 
focusing an active university role in entrepreneurship and contracts with private sector for IP commercialization.

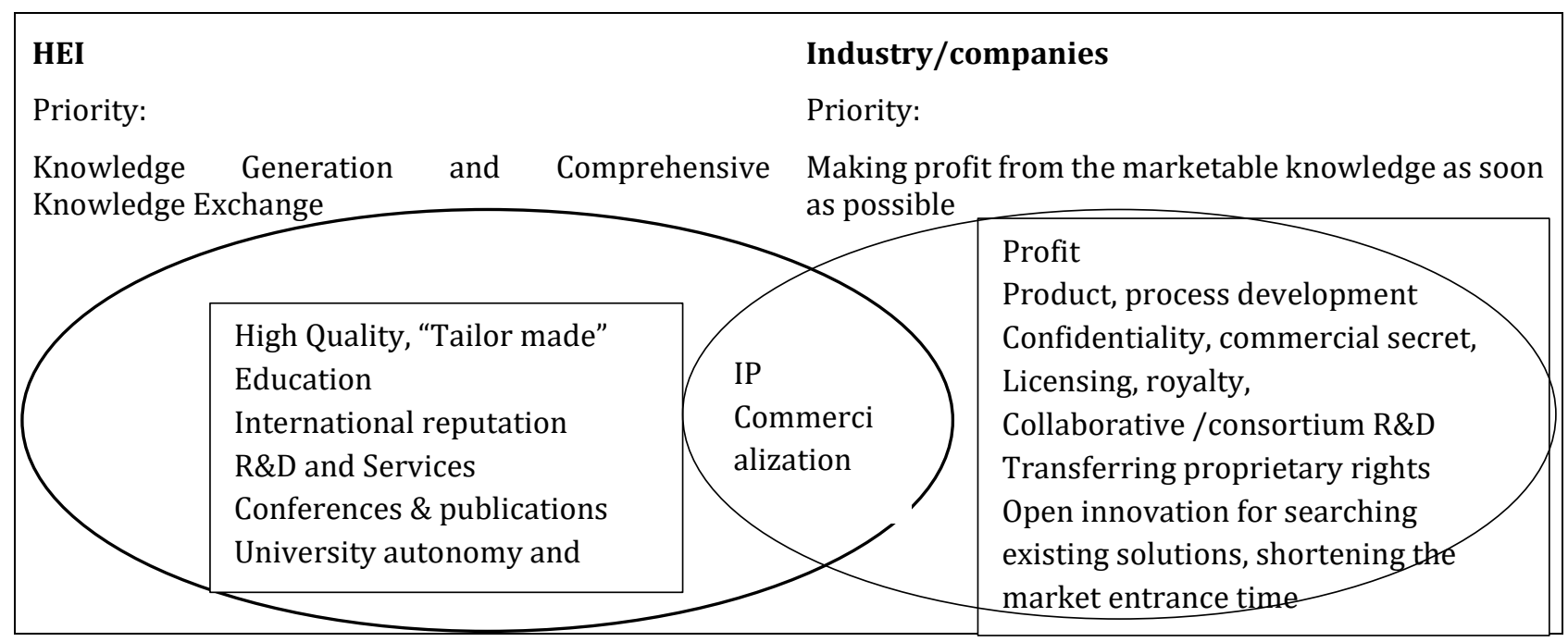

Figure 1. The different point of views from the HEI side and corporate side and the common cross-section of IP commercialization. Own edition

A critical point to the technology transfer success is the market and commercial validity of the object of transfer. To this purpose, it is true that universities and research entities hold an impressive number of patents, technologies and know-how but the ultimate decision of transferability is of the company based on market information.

The general purpose of technology transfer is to commercially exploit implementable, marketable, competitive research \& development results to market innovations. In this context, you have to make a clear difference between knowledge transfer and technology transfer ${ }^{1}$.

The successful and properly managed IP commercialization processes largely contribute to

- creating new jobs

- making money/profit

- promoting HEI's branding and reputation

- improving the competitiveness of the interested companies

- widening and deepening the already existing cooperation between the interested stakeholders or initiating a new networking

- create local/regional/national economic and social well-being

The main driving force for IP commercialization from university side (parenting with companies) can be:

- Application of R\&D results for satisfaction of social or economic demands

- Exposure to industry collaboration

- Involving additional source for further R\&D financing

\footnotetext{
1 Technology transfer means transfer of innovative solutions of problems that are protected by different intellectual property rights. Knowledge transfer is a broader term and covers other areas of research, including social sciences, as well as less formal transfer mechanisms.
} 
- Creating "private" R\&D fund

- Reward inventors/researchers

The same thing from the other (industry) side (partnering with HEI's) can be [3]; [4]:

- Research institutions are rich source of new ideas and technology

- Cheaper to support R\&D and to license-in technology

- Certain sector (e.g. Biotechnology industry) looks to academic collaborations for early stage cutting-edge technology solutions with high market potential.

\subsection{International Networks/Organisations supporting for HEI-industry Knowledge Exchange/IP commercialization [14]}

While the successful HEI's or PRO's IP commercialization process can play pivotal role in accelerating the different innovation processes, improving the economic competitiveness of the market actors, reshaping the social attitudes and organisational cultures, raising the IP awareness and other advantageous spill-over effects, on European level many international networks and organisation make concerted actions to help these valuable initiatives. The Table 1. below give a comprehensive overview about these communities.

\begin{tabular}{|c|c|c|}
\hline $\begin{array}{c}\text { Type of KE/IP } \\
\text { commercialization }\end{array}$ & iples & ples \\
\hline $\begin{array}{l}\text { Knowledge \& } \\
\text { Technology } \\
\text { Transfer/Spin-off } \\
\text { companies/Licensin } \\
\text { g }\end{array}$ & $\begin{array}{l}\text { There are interested stakeholders, which are } \\
\text { active solely or predominantly in the area of } \\
\text { spin-outs/licensing. These serve the needs of } \\
\text { the traditional 'technology transfer' } \\
\text { community and reflect the distinct set of } \\
\text { 'hard' skills needed in this area, such as } \\
\text { intellectual property law and securing } \\
\text { external finance. In addition, there is } \\
\text { important connections to enterprise/ } \\
\text { entrepreneurship, incubation and } \\
\text { leadership/management via strategic } \\
\text { contracts and R\&D partnerships. }\end{array}$ & $\begin{array}{l}\text { UK -Innovate UK } \\
\text { https://www.gov.uk/governm } \\
\text { ent/organisations/innovate- } \\
\text { uk, IPO, Praxis Auril } \\
\text { https://www.praxisauril.org.u } \\
\text { k/ } \\
\text { Europe - ASTP-Proton2 } \\
\text { https://www.astp4kt.eu/ } \\
\text { European Patent Office (EPO) } \\
\text { https://www.epo.org/index.ht } \\
\text { ml } \\
\text { Global - World Intellectual } \\
\text { Property Office (WIPO) } \\
\text { https://www.wipo.int/portal/ } \\
\text { en/index.html }\end{array}$ \\
\hline $\begin{array}{l}\text { Collaborative/cons } \\
\text { ortia R\&D contracts } \\
\text { and other forms of } \\
\text { multidisciplinary, } \\
\text { long-term strategic } \\
\text { partnerships. }\end{array}$ & $\begin{array}{l}\text { Research contracts and ling-term, } \\
\text { multidisciplinary strategic partnerships } \\
\text { represent another areas of practice, with a } \\
\text { large number of stakeholders involved in the } \\
\text { production of effective marketable products } \\
\text { and services. }\end{array}$ & $\begin{array}{l}\text { UK -Confederation of British } \\
\text { Industry (CBI) } \\
\text { (https://www.cbi.org.uk/abo } \\
\text { ut-us/), Innovate UK, } \\
\text { Europe - University, Industry } \\
\text { Innovation Network (UIIN) } \\
\text { https://www.uiin.org/ }\end{array}$ \\
\hline
\end{tabular}

\footnotetext{
2 The largest European knowledge and technology transfer network, ASTP-Proton operates as a non-profit organization involving 500 technology transfer experts from every EU member state. ASTP-Proton has crucial influence related promoting the activities of the PROGRESS-TT project and exploiting results of the HEI's and public research organisations (PRO) Technology Transfer Offices (TTO).
} 


\begin{tabular}{|c|c|c|}
\hline & $\begin{array}{l}\text { The strategic partnerships serve either } \\
\text { strengthening of the knowledge triangle } \\
\text { (education - R\&D - innovation) or develop } \\
\text { research infrastructure in the form of } \\
\text { cooperation between the companies and } \\
\text { HEI's, aiming the created RDI capacity } \\
\text { generates new competitive products and } \\
\text { services. } \\
\text { The organisations that are most active in this } \\
\text { area often possess strong links to the } \\
\text { business world and strongly focusing on the } \\
\text { mechanisms delivering the emerging market } \\
\text { needs, economic and social demands. }\end{array}$ & $\begin{array}{l}\text { European Institute of } \\
\text { Technologies (EIT) Knowledge } \\
\text { and Innovation Communities } \\
\text { (KIC) https://eit.europa.eu/ } 3 \\
\text { Hungary - Higher Education } \\
\text { and Industry Cooperation } \\
\text { Centres (FIEK) } \\
\text { https://nkfih.gov.hu/english- } \\
\text { 2017/research- } \\
\text { infrastructure/research- } \\
\text { infrastructure-180603 }\end{array}$ \\
\hline $\begin{array}{l}\text { Mutually access and } \\
\text { usage of research } \\
\text { infrastructure, } \\
\text { equipment and } \\
\text { facilities. }\end{array}$ & $\begin{array}{l}\text { Special community of practice can be } \\
\text { identified related to science parks and } \\
\text { incubators, with the UK Science Park } \\
\text { Association (UKSPA) being active in this field } \\
\text { It is logical to group equipment and facilities } \\
\text { under the same heading, but while there are } \\
\text { individual projects and initiatives in these } \\
\text { area, to date no stakeholder organisation has } \\
\text { emerged to take overall ownership }\end{array}$ & $\begin{array}{l}\text { UK - UK Science Park } \\
\text { Association (UKSPA) } \\
\text { http://www.ukspa.org.uk/, } \\
\text { NESTA } \\
\text { https://www.nesta.org.uk/ } \\
\text { Global - International } \\
\text { Association of Science Parks } \\
\text { (IASP) https://www.iasp.ws/ }\end{array}$ \\
\hline
\end{tabular}

Table 1. International Networks and Organizations supporting for HEI-industry Knowledge Exchange/IP commercialization based on [14] own edition

\subsection{Examples for EU programs that support European HEI's IP commercialization [10]; [12]; [15]}

In the course of the operational activities of the previously mentioned European HEI IP commercialization promoter networks, there are many EU financed programs/projects that can act as a complementary "catalyst" generating synergies between these network activities and the below reviewed programs.

Capacity-Building in Technology Transfer (CBTT-2014): Within EU H2020 Framework Program, this program aimed improving the professional competences of European HEI and PRO technology transfer offices (TTO) to make more efficient and effectively the IP commercialization processes organizing e-learning platforms, training, organizing workshops and boot camps and direct coaching and mentoring services have provided opportunities for many European TTO's experts.

InnovFin Technology Transfer Program: The objective of the program is to provide pre-seed capital investments for HEI's and PRO's Proof of Concept (PoC) and technology transfer activities. On the other hand, the initiative further generic aims to accelerate technological innovation and the development of early phase technologies for IP commercialization and encouraging establishment spin-offs. Inside the

\footnotetext{
${ }^{3}$ EIT is the EU's largest innovation community having mission taking into practice the „knowledge triangle”, strengthening the entrepreneurship, commercialization of IP's, widening and deepening the networks between universities and companies. This network includes 983 companies, 133 cities, regions and NGO's; 249 universities, 252 public research organisations and other 1500 partners across EU. Till now, roughly 900 new products were commercialized, 2000 spin-off or start-up company supported by seed or venture capital, 6100 new jobs created
} 
H2020 Framework Program, this program has been financed by European Investment Fund (EIF). The program will be ended in September 2020.

IRSUS: The mission of the project supports the European spin-offs and start-ups through the road to market and successful IP commercialization connect HEI's and Pro's research with industry, clients and investors.

PROGRESS-TT: The project aims ensuring that HEI's and PROs are better equipped to transfer valuable knowledge to industry. The project facilitates the exchange and sharing of experiences, capacity building between Europe's leading HEI's and PROs with the potential to commercialize their R\&D research results. In addition, the project helps for the interested stakeholders by gathering best practices and developing an applicable technology transfer tools, methods.

EIPIN-Innovation Society: This is a comprehensive project at the forefront of multidisciplinary R\&D, focusing on the role of IP as a complex adaptive system in innovation and commercialization. The $g$ European Intellectual Property Institutes Network (EIPIN), a consortium of leading research and training centres in the area of intellectual property. The project started on 1 March 2017.

\subsection{Challenges for the European universities that can hinder or slow-down IP commercialization}

The concept "European Innovation Paradox" was firstly used by the European Commission to define the European problem that having good higher education systems and public research organisations creating world-class knowledge and R\&D results but their efforts usually doomed to failure to commercialize these IP into marketable products, services and technologies. Furthermore, you can talk about "Extended European Innovation Paradox". This means that while out of the top 20 R\&D spender companies $30 \%$ are of European origin, out of the top 10 most innovative companies there aren't any European. Transforming European economies' success in basic research activities into commercial success seems to be difficult. [16]

The main reason beyond this unfavourable trend can be the lack of the strategic planning and efforts for the commercialization of the Intellectual Property from HEI side and the weak linkages to the business sphere. The Table 2 . below briefly summarise the challenges for the universities in the field of successful IP commercialization and the reasons beyond that.

\begin{tabular}{|l|l|}
\hline \multicolumn{1}{|c|}{ Problem } & \multicolumn{1}{|c|}{ The possible reasons beyond the given shortcoming } \\
\hline $\begin{array}{l}\text { Lack of relevant and } \\
\text { comprehensive } \\
\text { knowledge from HEI side }\end{array}$ & $\begin{array}{l}\text { Not understanding the emerging market needs and the } \\
\text { mechanism and the actors of the given market segments } \\
\text { No competencies or attitude to monitoring the market } \\
\text { Insufficient size of relevant and up-to-date cooperative education } \\
\text { (involving the business/industrial actors) at the HEI's }\end{array}$ \\
\hline $\begin{array}{l}\text { Weak linkages between HEI and } \\
\text { companies }\end{array}$ & $\begin{array}{l}\text { Lack of deep and wide industrial cooperation for deployment } \\
\text { technologies, products and services developed by social or } \\
\text { economic needs } \\
\text { HEI R\&D projects are not always successful or completely } \\
\text { irrelevant for the business sphere. }\end{array}$ \\
\hline
\end{tabular}




\begin{tabular}{|l|l|}
\hline & $\begin{array}{l}\text { The business opportunities of the implementable and marketable } \\
\text { R\&D results usually under-communicated or miss-communicated } \\
\text { between decision makers within and outside the university. }\end{array}$ \\
\hline $\begin{array}{l}\text { Insufficient HEI support for } \\
\text { establishing spin-off or start-up } \\
\text { companies }\end{array}$ & $\begin{array}{l}\text { The university staff are not motivated to establish spin-off } \\
\text { companies for commercialization of the previously developed } \\
\text { technologies, products or services. } \\
\text { Lack of entrepreneurial and business skills and competencies (e.g. } \\
\text { business model and business plan for the start-ups or spin-offs) } \\
\text { It would be necessary clearly, unambiguously determine whether } \\
\text { State-owned universities are entitled to own equity over spin-off } \\
\text { companies and in which circumstances. }\end{array}$ \\
\hline $\begin{array}{l}\text { HEI Technology Transfer Offices } \\
\text { does not operating effectively in } \\
\text { the practice }\end{array}$ & $\begin{array}{l}\text { Financial and organisational problems inside the traditional } \\
\text { university structures } \\
\text { Special, multidisciplinary competencies would be necessary } \\
\text { Lack of internal trust }\end{array}$ \\
\hline Missing IP management policy & $\begin{array}{l}\text { Conflicts of interests, aversions, fears } \\
\text { Bureaucratic obstacles, resistance from the top management of } \\
\text { HEI } \\
\text { Missing IP Management skills and knowledges }\end{array}$ \\
\hline
\end{tabular}

Table 2. Challenges for universities commercialize their intellectual assets based on [6]; [9]; [17] own edition

\subsection{HEI IP portfolio assessment before commercialization [17]; [18]}

Methods and techniques for IP assessment are generally divided into quantitative and qualitative methods. Quantitative methods used to calculate the financial value of the IP asset and include "cost", "market" and "income" based approaches. Qualitative methods provide a value guide through the rating and scoring of an IP asset based on factors that can influence its value as you can see in table 3.

\begin{tabular}{|c|c|c|}
\hline \multicolumn{2}{|r|}{ Quantitative methods } & Qualitative methods \\
\hline $\begin{array}{l}\text { Cost- } \\
\text { based }\end{array}$ & $\begin{array}{l}\text { One of the "oldest" classical tool. } \\
\text { Calculating the costs of the whole R\&D } \\
\text { project. In this way the sum of R\&D } \\
\text { expenditures and other costs e.g. } \\
\text { including patent application costs, } \\
\text { related directly to the development of } \\
\text { the IP asset are taken to be its monetary } \\
\text { value. } \\
\text { This method gives a useful benchmark } \\
\text { for IP value in cases where the future } \\
\text { uses and benefits of the products are not } \\
\text { yet evident and it can also be beneficial } \\
\text { for the future licence negotiations. }\end{array}$ & $\begin{array}{l}\text { These methods provide a non-monetary value } \\
\text { for the IP asset. Specific factors related and } \\
\text { have impact on the value of the IP asset used } \\
\text { to be chosen for analysis. The factors are rated } \\
\text { and scored to determine strengths and } \\
\text { weaknesses and to create a value guide. } \\
\text { Qualitative "value driver" based tools include } \\
\text { those which analyse patent data, specific } \\
\text { aspects of the patent application } \\
\text { documentation (number or quality of claims, } \\
\text { citations etc.). There are also qualitative } \\
\text { approaches which analyse and score more } \\
\text { general aspects related to the IP asset. These } \\
\text { indicators related to legal and IP protection } \\
\text { backgrounds, the technology and }\end{array}$ \\
\hline
\end{tabular}

${ }^{4}$ Spin-off companies in this case can be defined as independent companies originating from universities with the mission for commercialising the universities generated and marketable knowledges/IP. "Spin-offs" represent an opportunity to set up a business that is based on the university's technologies and know-how. The link and network established between the stakeholders usually mutually profitable and beneficial: it can serve as a platform for technology transfer, offering the HEI a more attractive perspective than licensing out individual patented technologies. Spin-offs can build a bridge between the innovation capacities of the HEI and the market for products and services. 


\begin{tabular}{|l|l|l|}
\hline $\begin{array}{l}\text { Market- } \\
\text { based }\end{array}$ & $\begin{array}{l}\text { This tool evaluate IP by looking at } \\
\text { current comparable transactions (for } \\
\text { example a license deal or a sale) } \\
\text { between independent parties. The } \\
\text { conditions and prices at which these } \\
\text { deals are made within the same or } \\
\text { similar industrial sector can give good } \\
\text { the Hel that will exploit it }\end{array}$ \\
$\begin{array}{ll}\text { indication about the value of the IP. } \\
\text { The comparable royalty rate method is } \\
\text { probably the most common and } \\
\text { involves identifying and analysing } \\
\text { licence transactions involving similar } \\
\text { products. }\end{array}$ \\
\hline $\begin{array}{l}\text { Income- } \\
\text { based }\end{array}$ & $\begin{array}{l}\text { This methods measure the potential } \\
\text { income and profit from an IP asset in the } \\
\text { future. This income stream is } \\
\text { discounted back to the date of the } \\
\text { valuation to give a present value for the } \\
\text { products. The value of the product is } \\
\text { adjusted for risk by changing the } \\
\text { discount rate depending on the risks } \\
\text { type related the development and } \\
\text { exploitation of the IP asset. }\end{array}$ \\
$\begin{array}{l}\text { Principles such as the discounted cash } \\
\text { flow (DCF) method calculate the } \\
\text { potential future cash-flows from the IP } \\
\text { asset and appropriately discount these. } \\
\text { The result is the present value of the IP } \\
\text { asset. Other examples the risk adjusted } \\
\text { netpresent value (rNPV) and relief from } \\
\text { royalty methods. }\end{array}$ \\
\hline
\end{tabular} \mid

Table 3. Summary of the different methodological tools for "monetarizing" of HEI IP assets based on [17]; [18] own edition

\subsection{The HEI IP Management and its pillars [9]}

As you can see at the beginning of this chapter in Figure 1., there are numerous ways for the existing knowledge exchange in case of HEI's. One of the possible ("academic") direction of this one can be the public knowledge sharing via publications (e.g. for moving ahead individual careers or put the university on the world-leading PRO's map), conferences, workshops, seminars, building-in their relevant and upto-date R\&D results in the educational activities and curriculum developments. The other ("business") direction can be the IP commercialization in different forms or combining both. All universities, researchers are free to decide which kind of direction they would like to realise.

The majority of the European university recognised the importance of the IP commercialization involving additional financial sources for R\&D, widening their networks, deepening the trust and brand building that can easily lead to corporate sponsorship in other areas as well (e.g. in the frame of 
corporate social responsibility). In this context, the HEI management has to create the internal and external conditions for the successful IP Management and commercialization. The first thing is awareness creation. It is essential that university staff be aware of the importance of IP commercialisation. They must also recognise that they can initiate and support the commercialisation process for example the technology they have created. Second component is training combining the previous scientific knowledge with business and entrepreneurial competencies, skill, because researchers and administrative staff should be able to support the commercialisation effective way (accurate and comprehensive documentation of R\&D, and number of "good practice" procedures for researchers can help this process). Faculties have to focus on education and R\&D. In order to do so, they need IPR support from the university administration for setting up their collaboration contracts with third parties and funding agencies. These contracts need to include suitable IP rules that facilitate subsequent commercialisation.

Companies have tendency supporting their business strategy with the IP they protect, for example the products and services that they sell. The licensing of IP is becoming a part of their overall business strategy. For HEI's, IPRs are also emerging as a business development tool which can be used to initiate additional collaborative/consortium R\&D projects with licensees. In order to maximise the value creation for all parties involved, underused IPRs licensed to third parties and/or may also establish the basis for spinning out companies. An alternative option for exploitation can be to assign/sell the technology to a third party.

HEI IP management based on the following pillars: creation, evaluation, protection and exploitation as you can see in the Table 4.

\begin{tabular}{|c|c|}
\hline Tools of IP Management & Process \\
\hline Overview and Assessment of IP & $\begin{array}{l}\text { Preparing inventor about the available } \\
\text { Intellectual assets } \\
\text { Using quantitative and qualitative } \\
\text { methodological tools for clarifying the potential } \\
\text { "financial" value of IP } \\
\text { Defining IP Management Strategy clarifying the } \\
\text { business model and commercialization routes }\end{array}$ \\
\hline Confidentiality, commercial secret & Non-disclosure agreements \\
\hline Capture of information & $\begin{array}{l}\text { Laptops, internal working documents on daily } \\
\text { basis }\end{array}$ \\
\hline Reporting & Invention disclosures \\
\hline $\begin{array}{l}\text { Protection } \\
\text { (you should ensure IP protection before it is } \\
\text { published) }\end{array}$ & $\begin{array}{l}\text { IPR (patent, design, trademark, utility model } \\
\text { protection, copyright) }\end{array}$ \\
\hline Cooperations, networking & $\begin{array}{l}\text { Collaborative and consortium agreements and IP } \\
\text { provisions in contracts using Lambert toolkit } \\
\text { templates clarifying criteria for ownership, } \\
\text { income (royalty) distribution }\end{array}$ \\
\hline
\end{tabular}

Table 4. Tools and processes of HEI IP management base on [9] own edition

First step for any HEI in building partnerships with the business sector for IP commercialization to have a clear and transparent IP policy that is formally approved by the university authorities and available for consultation by internal and external stakeholders. University IP policies generally cover all IP rights, in particular patents and copyright, but may also regulate the transfer of know-how. 
There are numerous European university that has been able for effective and efficient IP commercialization largely due to the adequate IP Strategy which generate revenue from IP.

\section{The forms of IP commercialization}

There are various formal and informal channels through which knowledge may be transferred. Among the most frequently-used formal means of knowledge transfer are [7]; [12]:

- licensing

- transferring proprietary rights

- collaboration/ sponsored research agreements

- technology/knowledge transfer agreements

- consultancy agreements

- franchising and establishment of spin-off and start-up companies

- patenting

The informal transfer of knowledge is becoming more and more important in the academic environment as the mobility of researchers and students is greatly contributing to the dissemination of knowledge worldwide. Knowledge can also be transferred through publications, teaching, conferences, courses, presentations, meetings and informal exchanges and personal contacts between scientists, academia and industry. Let me see in details of the main additional income generation IP commercialization processes.

\subsection{Technology transfer ${ }^{5}[6] ;[7] ;[12]$}

Business sectors that receive commercialization rights to a technology usually pay to the IP owner (university) license fees, royalty payments, and sometimes equity in the resulting venture. Universities usually negotiate with technology transfer to generate revenue for their institutions and for funding their R\&D projects. HEI can set up a technology transfer office (TTO) that operates as a bridge between the companies and the university, identify, evaluate the potential inventions for commercialization and coordinate licensing to the interested enterprises.

\subsection{Licencing [3]; [10]; [12]}

Currently, universities used to prefer licencing processes as IP commercialization form. For licensing the protected IP, HEI's identify those companies that are operating in the same value chain as their patented invention/solution and contact these companies for licensing offers. The licencing contracts should contain the following terms: a) License grant (Exclusive or non-exclusive; Field of use; Territory); b) License Consideration (Upfront fee; Maintenance fees / Minimum annual royalty; Royalties, Other Milestones, equity).

\footnotetext{
${ }^{5}$ Technology transfer means developing technologies for commercial, business purposes by "passing over" the information or manufactured devices, materials or prototypes, by legal tools, or through the delivery of services, or through direct sales.
} 
The license agreement has many advantages over the "traditional" technology transfer, since it does not remove the intellectual property from HEI and many safeguards can be included in the contractual terms which, if not fulfilled, if the assets are not used as expected, the license agreement is terminated and the right of exploitation is restored to original location. Briefly, license has many other benefits carries with it what the transfer excludes:

- such is to be made available on a time or area basis,

- but it is also common that the HEI providing the development rights

- if they are not covered by the license agreement, the license agreement is terminated

\subsection{Transferring IP Rights [9]}

Another possibility for the commercialization is the assignment of patent which involves the sale and transfer of ownership of property rights in a given patent(s) and any applications for such patents by the assignor to the assignee. This is one-time payment method where the patent owner prefers to receive a lump sum price, at the time of the assignment of his/her property, rather than collecting royalties and transferring risks arising from reduced royalties due to technical failure, regulatory failure, market failure and competing products to the assignee.

\subsection{Joint Ventures [12]}

Many companies establishing collaborative innovation joint venture with universities/research institutes, joint ownership of IP rights has become very common. Companies work in collaboration with universities to work with their developers, technology and design houses. Revenue generated by the collaborative arrangement and strategic alliance may be shared equally between the joint parties.

\subsection{Collaborative or consortium R\&D [4]; [5]; [11]}

Universities and their external partners from various different reasons undertaking collaborative R\&D projects, such as improving their competitive advantage, developing innovative products and services and tackling societal challenges. In this context, the most important step identifying partners for the collaborative $R \& D$ projects, negotiating the partnership, involving every interested stakeholder with different competencies and skill in these projects, increasing professionalization of HEI's human resources and harmonising/synthesizing the multiple goals into commonly shared joint future vision.

Before any collaborative project begins, the parties should agree on the important items they wish to control in the work and in the outputs from that work. These items should then be set out in a collaborative agreement, which should include terms for management of the IP.

In this way, the Guidance for University and business collaboration agreements: Lambert Toolkit, which consist of different collaborative and consortium (if the number of cooperating partners more than two) agreement templates can be an effective tool in the interested stakeholders' hands [19]. These ones can be regard as initial point for the negotiations among the interested parties and their use is not compulsory, but they can largely contribute to minimise reduce time and costs of the process. The decision makers have to take decision which of these models fit best to the previously proposed business 
objectives and negotiate with the other party to reach consensus and signed the "selected and tailormade" agreement before work on the project begins.

The aim of theses sample collaboration and consortia contracts is to promote innovation processes, and make collaboration closer with companies sharing of knowledge mutually beneficial manner. You can see the essence of these template on the below Table 5 .

\begin{tabular}{|c|c|c|c|c|}
\hline \multicolumn{3}{|c|}{$\begin{array}{c}\text { Collaboration contract types } \\
\text { (2 parties intend to collaborate each other's - } \\
\text { HEI's or HEI-company) }\end{array}$} & \multicolumn{2}{|c|}{$\begin{array}{l}\text { Consortium contract types } \\
\text { (more than } 2 \text { parties intend to } \\
\text { collaborate each other's) }\end{array}$} \\
\hline No. & Conditions and principles & $\begin{array}{l}\text { Owner of } \\
\text { IPR }\end{array}$ & Category & Condition and principles \\
\hline 1. & $\begin{array}{l}\text { Collaborator has non-exclusive } \\
\text { rights to use in specified field; no } \\
\text { additional sub-licences }\end{array}$ & University & A & $\begin{array}{l}\text { Each member of the consortium } \\
\text { owns the IP in the results that it } \\
\text { creates. They grant each other } \\
\text { party a non-exclusive licence to } \\
\text { use those results for any other } \\
\text { purpose. }\end{array}$ \\
\hline 2. & $\begin{array}{l}\text { Collaborator may negotiate } \\
\text { further licence to some or all HEI } \\
\text { IP }\end{array}$ & University & B & $\begin{array}{l}\text { The other parties assign their IP } \\
\text { in the results to the lead } \\
\text { exploitation party (or the lead } \\
\text { exploitation party granted an } \\
\text { exclusive licence). }\end{array}$ \\
\hline 3. & $\begin{array}{l}\text { Collaborator may negotiate for an } \\
\text { assignment of some HEI IP }\end{array}$ & University & C. & $\begin{array}{l}\text { Each party takes an assignment } \\
\text { of IP in the results that are } \\
\text { germane to its core business } \\
\text { and exploits those results. }\end{array}$ \\
\hline 4. & $\begin{array}{l}\text { HEI has right to use for non- } \\
\text { commercial purposes }\end{array}$ & Collaborator & $\mathrm{D}$ & $\begin{array}{l}\text { Each consortium member owns } \\
\text { the IP in the results that it } \\
\text { creates. They grant each other } \\
\text { party a non-exclusive licence to } \\
\text { use those results for the } \\
\text { purposes of the project only. If } \\
\text { any consortium member wishes } \\
\text { to exploit another's IP, they } \\
\text { must negotiate a license or } \\
\text { assignment about the IP }\end{array}$ \\
\hline 5. & $\begin{array}{l}\text { Both party has right to exploit } \\
\text { certain results created during the } \\
\text { project and takes assignment of } \\
\text { those results. HEI has right to use } \\
\text { for education and R\&D purposes, } \\
\text { the Collaborator for research } \\
\text { purposes. }\end{array}$ & $\begin{array}{l}\text { University } \\
\text { and } \\
\text { Collaborator }\end{array}$ & & \\
\hline 6. & $\begin{array}{l}\text { Contract research: no publication } \\
\text { by HEI without Collaborator's } \\
\text { permission }\end{array}$ & Collaborator & & \\
\hline 7. & $\begin{array}{l}\text { HEI has right to use for education } \\
\text { and R\&D purposes }\end{array}$ & Collaborator & & \\
\hline
\end{tabular}

Table 5. Lambert Toolkit's templates based on [1]; [19] own edition 


\subsection{HEI start-ups and incubation [3]; [12]}

The HEI's spin-off or start-up companies mission are to take into practice the marketable university own $R \& D$ results transforming them into tangible commercial/business success. These special forms of innovative, knowledge and technology-oriented enterprises can operate as a subsidiary of the university or it can be VC Fund created. Crucial to clarify the motivational factors and the terms for university staff involvement into the spin-offs/start-ups. In this context, you can make differences between the permitted and the prohibited activities that can be below summarised as you can see in the Table 6 . below.

\begin{tabular}{|l|l|}
\hline \multicolumn{1}{|c|}{ University staff has to } & \multicolumn{1}{|c|}{ University staff should refrain from } \\
\hline $\begin{array}{l}\text { Separate their own on-going university R\&D } \\
\text { works from spin-off/start-up tasks }\end{array}$ & $\begin{array}{l}\text { Negotiate with the University on behalf of the } \\
\text { company }\end{array}$ \\
\hline $\begin{array}{l}\text { Understand clearly that their primary } \\
\text { commitment is to the University }\end{array}$ & $\begin{array}{l}\text { Accept gifts or sponsored fringed benefits from } \\
\text { the company }\end{array}$ \\
\hline $\begin{array}{l}\text { Only advisory/consulting roles with the spin- } \\
\text { off/start-up company }\end{array}$ & $\begin{array}{l}\text { Involve other university staff and current } \\
\text { students in spin-offs activities }\end{array}$ \\
\hline Limited consulting time for the spin-off/start-up & $\begin{array}{l}\text { Using university infrastructures and facilities for } \\
\text { company purposes }\end{array}$ \\
\hline $\begin{array}{l}\text { Take a leave of absence if engaging in a } \\
\text { management role }\end{array}$ & $\begin{array}{l}\text { Involve junior faculty who are in a dependent role } \\
\text { in company activities }\end{array}$ \\
\hline
\end{tabular}

Table 6. The different activities related to HEI's spin-offs/start-ups based on [3]; [12] own edition

\section{7. "Patent enforcement" [8]}

The commercial relevance of the invention is the most difficult question, as it will not make any sense to patent an invention if there is no potential for value creation. The patentability of the invention should also be assessed.

Inventorship on a patent is legal requirement, therefore inevitable to clarify who will be the inventor. Ownership of the patent usually arising from the inventorship. In most European countries, employees who create inventions in the course of their R\&D work assign any patents and other IP to their employers for example to the university. However, there may be exceptions to this. (In Italy and Sweden, inventors at universities have special ownership rights). So parties involved in transnational collaborative projects have to know if the laws are different for any of the partner countries.

\section{How to measure the success of HEI IP commercialization?}

To measure the effectiveness of university IP commercialization, an Expert Group convened by the European Commission is recommending the following indicator checklist, as you can see in the Table 7. [1]

\begin{tabular}{|l|l|}
\hline \multicolumn{1}{|c|}{$\begin{array}{c}\text { Main indicators } \\
\text { Number of }\end{array}$} & \multicolumn{1}{c|}{$\begin{array}{c}\text { Supplementary indicators } \\
\text { Number of/share of }\end{array}$} \\
\hline Research agreements & Knowledge transfer involving SMEs \\
\hline Patent applications and granted patents & $\begin{array}{l}\text { Knowledge transfer involving domestic vs } \\
\text { foreign firms }\end{array}$ \\
\hline
\end{tabular}




\begin{tabular}{|l|l|}
\hline Licenses implemented and income earned & $\begin{array}{l}\text { Knowledge transfer involving the region where } \\
\text { the PRO is based }\end{array}$ \\
\hline Invention disclosures & Exclusive licenses \\
\hline Established university spin-offs/start-ups & $\begin{array}{l}\text { Share of the (valid) patent portfolio that has ever } \\
\text { been licensed }\end{array}$ \\
\hline & $\begin{array}{l}\text { Areas of technology where patents have been } \\
\text { obtained }\end{array}$ \\
\hline & Patent share of licensing income \\
\hline
\end{tabular}

Table 7. Relevant indicators that can measure the commercial success of IP exploitation. Based on [1] own edition

In addition, basic data that are needed to assess performance include:

- Size of the knowledge transfer office (number of staff);

- Total budget of the knowledge transfer office;

- Outsourcing of knowledge transfer office services (i.e. does the knowledge transfer office outsource

- $R \& D$ expenditures of affiliated university.

\section{Selected EU HEI best practices for accelerating IP commercialization [20]}

\subsection{Open innovation ${ }^{6}$ - Ideas exchange platform at Cracow University of Economics TTO}

Matching information about academic research (supply) and the need for scientific methods to solve problems (demand) is a difficult task for entrepreneurs. Obtaining information about specific research profiles is time-consuming and R\&D is not ready for the businesses itself.

Transition processes in countries behind the former 'iron curtain' need innovative impulses to decrease the distance to most developed economies of the EU. This innovative boost should result from knowledge and technology transfer between R\&D sector and business 'actors'. This idea is at the basis for the Science and Economy Project, which is an initiative of Cracow University of Economics to bring academia and business closer together and create a common platform (http://www.naukaigospodarka.pl) for the exchange of information. The objective is that researchers can offer a profile of their own research, and entrepreneurs can list their need for R\&D solutions to implement academic ideas, functioning as a tool for giving incentives for researchers to disclose ideas via the platform for industry. The project is directed by CUE TTO. It is targeted representatives of science and business sectors who are interested in the issues of commercialization and the transfer of technology that is generated in PROs, to the economy. Users of this platform cooperation between university and industry was launched by joint submitting of emerging ideas and discussing thoroughly the problems with comprehensive win-win approach, looking for mutually beneficial solution. In 2015 there are 267 listings from academics and 87 listings from business and industry which makes it a great tool giving incentives for researchers to disclose IP and scout ideas via the platform from industry.

\footnotetext{
${ }^{6}$ Open Innovation process combine internal and external ideas as well as internal and external ways to market exploiting synergies in the field of development of new products, services and technologies.
} 


\subsection{Internal Seed Funding at Imperial Innovations [21]; [22]}

Imperial College London is a science-based university with an international reputation for excellence in education and R\&D with 14,700 students and 8,000 staff, attracting undergraduates from more than 125 countries. The HEI's profile: natural, life, engineering and business sciences and applying these skills to enterprises. Developing an idea or invention into a spin-off/start-up requires investment to help product development, proof-of-concept and proof-of-market. This so-called seed-funding can be difficult to obtain due to high hidden risks, unknown pitfalls and unpredictable events. "The University Challenge Seed Fund" established by the British Government in 1998 with $£ 45 \mathrm{~m}$ available in the first round and a further $£ 15 \mathrm{~m}$ in 2001 . The Fund allocated seed money for 19 universities to spend completed with $25 \%$ own resources on launching spin-offs or start-ups. There was no restriction on who would manage the funds so the universities could take a flexible approach in building-up their own financing schemes. Some universities teamed up with local venture capital firms and angel firms and gave the money to them to act as a local VC. Imperial College took the money in-house, under Imperial Innovations, and hired investment managers to work for them. At this point, Imperial Innovations created in-house investment capability and made investment in university spin-offs. The technology transfer operation established as independent company, called Imperial Innovations in 1997, 100\% owned by the university. Other decision was introducing Imperial Innovations on the London Stock Exchange, raising $£ 20 \mathrm{~m}$ in capital. The university retained $80 \%$ ownership in Imperial Innovation and $20 \%$ was sold to investors on the stock exchange. Imperial Innovations has strict criteria for funding new businesses (applicability, marketability, income generation capability of the business plan and the cutting-edge technological solutions of new products). The academic founder is rarely become CEO of the company. The teams that operate each spin- off consist of professional management recruited by Imperial Innovations.

\subsection{Commercialisation Boot Camps and Venture Launch Accelerator at University College Dublin [23]}

University College Dublin (UCD) is Ireland's largest university since 1854 with over 30,000 students and 1,500 academic staff, consisting seven colleges covering the main fields of sciences. Promoting entrepreneurship is a challenging job for the university. Researchers, staff and students skilled in their academic research field and in creating radically new inventions and technologies, but they often lack competencies leading to successful commercialization and the required competences. The UCD Commercialisation Bootcamp is a support program by UCDInnovation for academics and staff at University College Dublin understanding of the IP commercialization process (market problems, opportunities and validation, commercialization ways, business plan, involvement external financial sources). UCDInnovation also operates the Venture Launch Accelerator program making easier set-up of new ventures based on UCD intellectual property. Workshops help the researchers acquiring the knowledge, skills and understanding that will be required to develop teams and technologies into commercial ventures. 


\subsection{Proof-of-concept funding and technology assessment at KTH Royal Institute of Technology [24]}

Established in 1827, KTH Royal Institute of Technology is the largest and oldest technical university in Sweden. KTH has more than 18,000 students and about 5,000 employees. KTH is organized into 9 schools and around 40 departments and research centres focusing E- science, IT and mobile communication, Transport research, Production engineering, and Molecular biosciences. European trend, that inventions developed at universities do not reach marketable product stage where their business utility is proven would without financial resources (capital). At the same time, technological and market validation of the idea is a prerequisite for a new products, technology to continue attracting external investors to become successful innovators for the benefit of society. Due to the high risk of return and the lack of proof of concept (PoC) external investors have tendency to reject the cooperation. KTH Innovation was established in 2007 as an internal department of KTH for providing resources and competencies to support researchers throughout the process of creating a commercial product or service based on their own R\&D results. KTH Innovation has a team of about 30 people, including 6 business development coaches that focus on different research and technology areas within KTH. The majority of business development coaches have engineering background and experience of working in start-ups or industrial companies. KTH Innovation established a proof-of-concept (PoC) funding programme called VFT-1 (Verifiering för Tillväxt). The goal of the VFT-1 programme is to take a project to commercialization or prepare it for a more rigorous commercial and technical verification. The PoC program financial sources arising $50 \%$ from KTH, 30-40 \% from the Swedish Government, 10$20 \%$ from EU programmes. VFT-1 programme funds about $40-50$ projects per year with an average investment per project of around 10,000 euro. KTH Innovation does not launch a call for PoC funding applications. Instead, projects used to be selected with the support of business development coaches.

\section{Conclusions}

While you can deal with wide range of higher education institutional types, possessing different strengths, values, organisational cultures, different objectives, and different business models arising from the previous ones. That can be the reason that IP management will show significant differences in every university, therefore there is no universal IP model or strategy. Instead, a strategy should be "tailor-made" based on the business model and other local features of the given HEI. Nevertheless, this means opportunity and responsibility at the same time for the European universities to find new individual ways to finance their activities, building up their brands, widening and deepening their network via trust-building, changing the former "traditional university" attitudes connecting closer with the business sphere and transforming themselves into "entrepreneurial universities" maintaining the competitive advantages. [25]

The following recommendations, which based on the international best practices, intend to give several implementable practical tips for the universities management taking into practice successful commercialization processes of intellectual assets elements independently the educational and service "profile", organisational structure, culture, location of the given HEI.

- R\&D exploitation activities cannot be independent of the academic environment, and therefore in the creation of knowledge making researchers of central importance interested in research should also be reflected in the career model. Therefore, we recommend that 
should be emphasized among the evaluation factors of the quality and performance-based career development system and innovation and research exploitation results.

- Based on the international best practices, you can draw the conclusion that inside the higher education institutional organizations, it is inevitable to set up an independently operating IP management and commercialization unit with staff having multidisciplinary, $\mathrm{R} \& \mathrm{D}$, business and managerial competencies. In addition to, the trust-building among the interested internal and external stakeholder can be also crucial that serve the base for the mutually beneficial cooperation forms.

- Institutions should develop and publish spin-off policy, which allows employees and students there and encourages them to participate, as appropriate engage in spin-offs when setting up businesses, as well which clarifies the long-term relationship between spin-offs and institutions.

- The universities should make efforts to move toward the "open innovation" approach widening their networks and minimizing the innovation cycle time, saving development costs. A website for scouting IP/ideas and a quarterly published journal has proven to be an efficient tool for European TTO to engage researchers to disclose their ideas and facilitate the early stages of the commercialization process.

- Recognizing that the exploitation of intellectual property is a long-term investment, the institution strives to establish an institutional financial foundation that supports the development of its own research results through the proof of concept (PoC) phase to facilitate the IP commercialization. Due to PoC grants can be similar to traditional R\&D grants, the main challenge is $\mathrm{PoC}$ funds so that they actually support business exploitation activities and not additional HEI R\&D are used by university staff to continue their previous activities.

\section{Summary}

IP management and commercialization are the cornerstones of every European university activities, and it can be regarded as effective tool to improve the competitiveness of the interested stakeholders and taking into practice in many forms the HEI's business goals. The challenge related how IP can be used strategically in an individual university in "tailor-made" manner taking into consideration the different circumstances and local features. The emerging needs for closer links to business sphere and contributing to solve real social and economic problems generates new ways for IP regimes, especially managing and protecting IP rights and accelerating the commercialization process providing institutional conditions and initiatives make more efficient and effective the IP system. Independently from the economic climate, HEI's considering greater investment in knowledge transfer, including recognition and protection of IP, will require an appropriate return to the university.

\section{Acknowledgement}

This work was supported by Basic research project in the field of Laser-beam - technologies and energy at the Edutus College, complemented by knowledge transfer and activities aimed at enhancing enterprises linkages and social engagement (in Hungarian: "Lézertechnológiai és energetikai alapkutatás megvalósítása az Edutus Főiskolán, tudástranszfer, továbbá a vállalati 
kapcsolatok és a társadalmi szerepvállalás erősítését célzó tevékenységekkel kiegészítve”). Project identification No.: EFOP-3.6.1-16-2016-000.

\section{References}

[1] Intellectual Asset Management for universities Intellectual Property Office of UK Universities https://assets.publishing.service.gov.uk/government/uploads/system/uploads/attachment_d ata/file/308072/ipasset-management.pdf May 25, 2020

[2] United Nations Economic Commission for Europe: Intellectual Property Commercialization POLICY OPTIONS AND PRACTICAL INSTRUMENTS United Nations, Geneva (Switzerland) 2011 ISBN: 978-92-1-117053-5 http://www.unece.org/fileadmin/DAM/ceci/publications/ip.pdf May 25, 2020

[3] The European IPR Helpdesk: Your Guide to IP Commercialisation https://aineetonansainta.fi/wp-content/uploads/2019/05/EU-IPR-Guide-CommercialisationEN.pdf May 28, 2020

[4] Dr. Guriqbal Singh Jaiya: University-Industry Partnerships: Role of Intellectual Property WIPO Small and Medium-Sized Enterprises Division presentation

[5] Lidia Borrell-Damian, Rita Morais and John H. Smith: University-Business Collaborative Research: Goals, Outcomes and News. Assessment Tools EUA Publications 2014 ISBN: 9789078997504

[6] Farizah-Binti-Mamat-alias-Mohd-Nor-Shashazrina-Binti-Roslan: Critical-Success-Factors-CsfsOn-Technology-Transfer-Effectiveness-In-Manufacturing-Industry-A-Critical-Review International Journal of Business, Economics and Law 2012, Vol. 1 ISSN 2289-1552

[7] Aastha Singhal: How to commercialize IP - Roadmap for Universities to Generate Revenue from IP http://ttconsultants.com/blog/how-to-commercialize-ip-roadmap-for-universities-togenerate-revenue-from-ip/ May 30, 2020

[8] https://ec.europa.eu/invest-in-research/policy/ipr_en.htm May 25, 2020

[9] https://www.wipo.int/export/sites/www/policy/pdf/en/ui_checklist.pdf May 25, 2020

[10] https://www.epo.org/learning-events/materials/kit/download.html May 30, 2020

[11] Responsible Partnering Guidelines - Joining Forces in a World of Open Innovation: Guidelines for Collaborative Research and Knowledge Transfer between Science and Industry. 2009 http://www.eua.be/activities-services/projects/current-projects/research-andinnovation/Responsible-PartneringInitiative.aspx. May 30, 2020

[12] Knowledge Transfer Study 2010-2012, Final Report; European Commission DG Research and Innovation 2013 ISBN 978-92-79-32388-1

[13] https://www.astp-proton.eu/organisation/committee/national-associations-advisorycommittee/ May 30, 2020 
[14] https://www.research-consulting.com/wp-content/uploads/2019/04/Effectivepractice-in-KE-Published-report.pdf May 30, 2020

[15] ttps://www.eif.org/news_centre/publications/innovfin_technology_transfer.pdf May 30,2020

[16] http://innomine.com/blog/extended-european-paradox May 30, 2020

[17] Péter Káldos: IP valuation at Research Institites. An essential tool for technology transfer Hungarian Intellectual Property Office 2011 ISBN 978-963-9157-66-8 https://www.sztnh.gov.hu/hirek/kapcsolodo/IP_Valuation_for_Technology_Transfer_EN_web. pdf

[18] WIPO: Valuation of intellectual property: What, why and how? WIPO Magazine, September/October 2003. https://www.wipo.int/export/sites/www/wipo_magazine/en/pdf/2003/wipo_pub_121_200 3_09-10.pdf

[19] https://www.gov.uk/guidance/university-and-business-collaboration-agreementslambert-toolkit May 31, 2020

[20] https://www.astp4kt.eu/ideas-exchange-platform-at-cracow-university-of-economicstto/ May 31, 2020

[21] https://www.astp-proton.eu/internal-seed-funding-at-imperial-innovations/ May 31, 2020

[22] https://www.imperial.ac.uk/research-and-innovation/research-office/funderinformation/funding-opportunities/internal-funding-opportunities/ May 31, 2020

[23] https://www.astp4kt.eu/commercialisation-boot-camps-and-venture-launchaccelerator-at-university-college-dublin/ June 1, 2020

[24] https://www.astp4kt.eu/proof-of-concept-funding-and-technology-assessment-at-kthroyal-institute-of-technology/ June 1, 2020

[25] https://www.weforum.org/agenda/2019/05/europe-s-most-innovative-universities2019 June1, 2020 